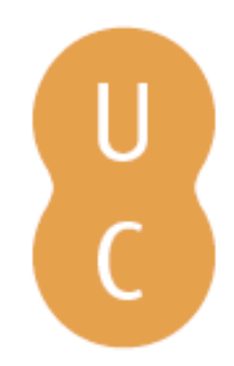

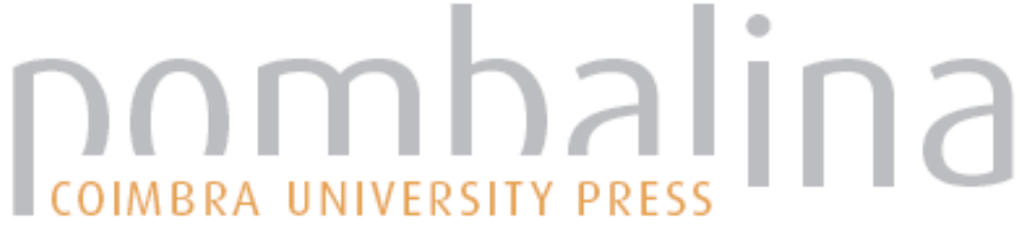

Adaption of the profitability estimation focused on benefits due to personal affection

Autor(es): $\quad$ Printz, Stephan; Vossen, René; Jeschke, Sabina

Publicado por: Imprensa da Universidade de Coimbra

URL

persistente:

URI:http://hdl.handle.net/10316.2/38157

DOI:

DOI:http://dx.doi.org/10.14195/978-989-26-1039-9_11

Accessed : $\quad$ 26-Apr-2023 16:06:27

A navegação consulta e descarregamento dos títulos inseridos nas Bibliotecas Digitais UC Digitalis, UC Pombalina e UC Impactum, pressupõem a aceitação plena e sem reservas dos Termos e Condições de Uso destas Bibliotecas Digitais, disponíveis em https://digitalis.uc.pt/pt-pt/termos.

Conforme exposto nos referidos Termos e Condições de Uso, o descarregamento de títulos de acesso restrito requer uma licença válida de autorização devendo o utilizador aceder ao(s) documento(s) a partir de um endereço de IP da instituição detentora da supramencionada licença.

Ao utilizador é apenas permitido o descarregamento para uso pessoal, pelo que o emprego do(s) título(s) descarregado(s) para outro fim, designadamente comercial, carece de autorização do respetivo autor ou editor da obra.

Na medida em que todas as obras da UC Digitalis se encontram protegidas pelo Código do Direito de Autor e Direitos Conexos e demais legislação aplicável, toda a cópia, parcial ou total, deste documento, nos casos em que é legalmente admitida, deverá conter ou fazer-se acompanhar por este aviso. 
IMPRENSA DA UNIVERSIDADE DE COIMBRA

COIMBRA UNIVERSITY PRESS

\section{ASSESSMENT \\ METHODOLOGIES}

ENERGY, MOBILITY AND OTHER

REAL WORLD APPLICATION

\section{PEDRO GODINHO \\ JOANA DIAS}

EDITORS

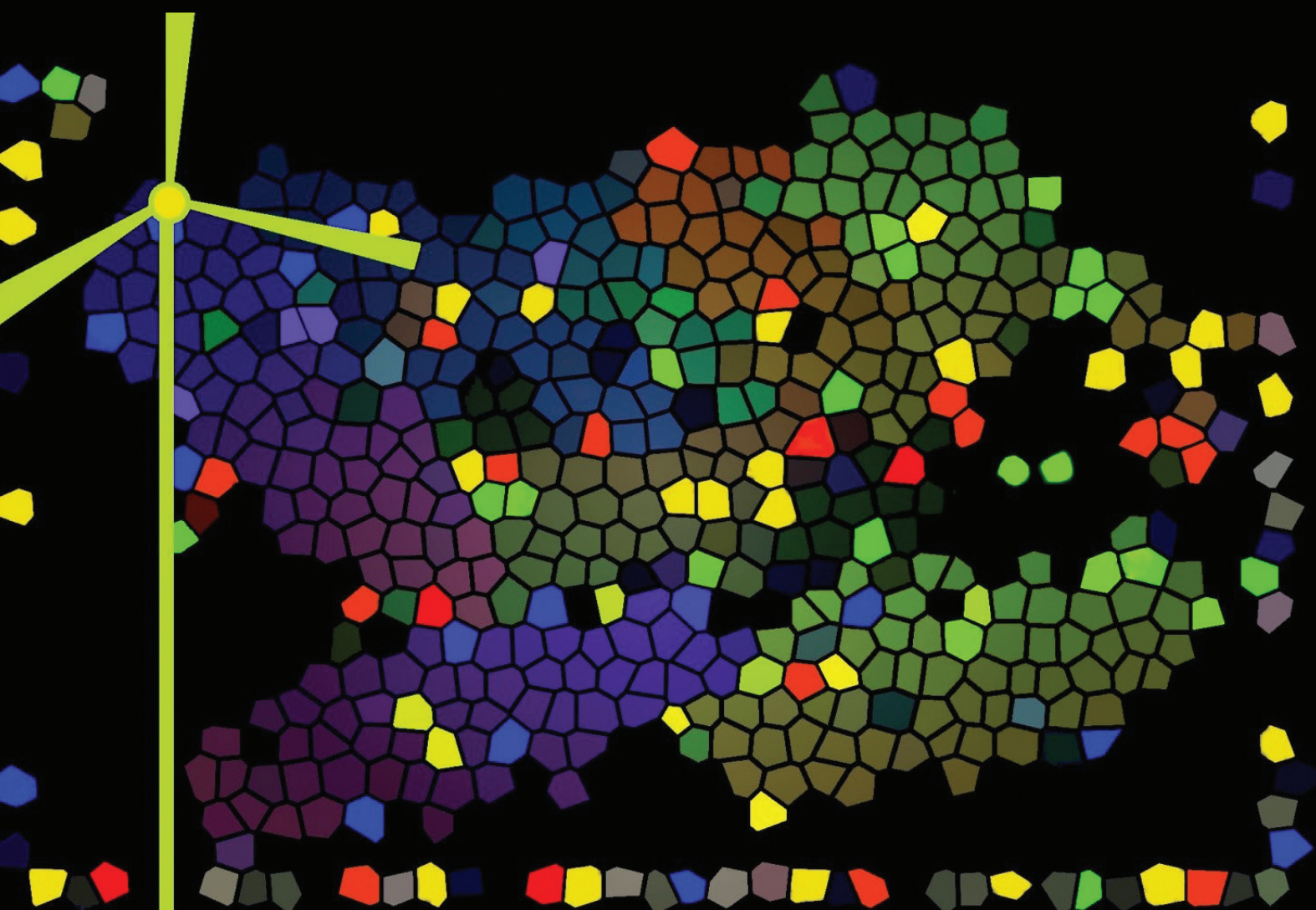




\title{
ADAPTION OF THE PROFITABILITy ESTIMATION FOCUSED ON BENEFITS DUE TO PERSONAL AFFECTION
}

\author{
Stephan Printz ${ }^{1}$, René Vossen ${ }^{1}$ and Sabina Jeschke ${ }^{1}$
}

\begin{abstract}
:
Strategic investment decisions are characterized by high innovation potential and long term effects on the competitiveness of enterprises. Due to uncertainty and risk in this complex decision-making situation, the need for well-structured support activities arises. A method that considers cost and the long-term added value is the cost-benefit effectiveness estimation. One of those methods is the "profitability estimation focused on benefits - PEFB"-method (trans. Savelsberg 2008) developed at the institute of management cybernetics at RWTH Aachen University in 2000, by WEYDANDT in the course of his PhD. This method copes with the challenge of strategic investment decision by integrating long term non-monetary aspects as well as by mapping the chronological sequence of an investment within the organisation's target system. For that reason, this method is characterised as a holistic approach for the evaluation of costs and benefits of an investment. In applying this participation-oriented method in business environment, the overall interdisciplinary investment teams were formed by more than 500 participants. Due to feedback of these participants within accomplished assessments, a survey with 110 participants was conducted focussing on the statements of verbal probability. The results of the survey identified a structural deficit in the conception of the methodology regarding the estimation of probabilities due to personal affection. This paper describes the well-structured PEFB-method to reduce risk and uncertainty in decision making progress. Moreover, the results of the survey concerning the bias due to personal affection within the evaluation process are
\end{abstract}

\footnotetext{
${ }^{1}$ Institute for Management Cybernetics e.V. assoc. Institute of RWTH Aachen University

E-mails: stephan.printz@ima-zlw-ifu.rwth-aachen.de, rene.vossen@ima-zlw-ifu.rwthaachen.de, sabina.jeschke@ima-zlw-ifu.rwth-aachen.de
} 
addressed. Finally, to achieve more accurate PEFB-method results, recommendations for an adaption of the PEFB are given.

Keywords: Multi-Criteria Decision, Cost-Benefit Analysis, Risk and Uncertainty Analysis, Profitability Estimation Focused on Benefits, PEFB-method.

\section{Introduction}

Literature just like practice shows that capital budgeting has not always distinguished strategic types of investment (Graham \& Harvey, 2001). Latest advances in research give evidence that there is substantial need for distinction in strategic investment decisions (Alkaraann \& Northcott, 2006). Strategic investment decisions (SID) are defined as

“(...) substantial investments that involve high levels of risk, produce hard-to-quantify (or intangible) outcomes and have a significant longterm impact on corporate performance." (Alkaraan \& Northcott, 2006)

In addition, Carr \& Tomkins point out that there is also an effect on the whole organisation regarding the competitiveness (Carr et al., 2010). Typical examples for SID are companies' mergers and acquisitions, e.g. a new assembly line, advanced technology of manufacturing or the launch of new software (Van Cauwenbergh et al., 1996; Slagmulder et al., 1995; Accola 1994). Controlling the complexity and uncertainty surrounding strategic investment decisions presents particular challenges to the management (Alkaraan \& Northcott, 2006; Dempsey, 2003; Slagmulder, 1997). For this reason, an efficient information search and evaluation is necessary (Preißler, 1991). Especially for the evaluation of accounting SID, there is a need to pay more attention to scenario-based techniques (Cornelius et al., 2005; Alessandri et al., 2004; Miller \& Waller, 2003). Thus, SID have a greater need to pay attention to probability of occurrence (Martzoukos \& Trigeorgis, 2002). Field studies give evidence that traditional profitability analysis to assess SID is supplanted by substantial sophisticated techniques in terms of linking qualitative and financial aspects (Alkaraan \& Northcott, 2006; Adler, 2000; Slagmulder et al., 1995). While the quantification and 
assignment of cost is examined extensively, there are less methods for the quantification and assignment of long term benefits (Schönheit, 1996; Zangemeister, 1994). New sophisticated techniques face this challenge for the quantification of benefits and the estimation of their impacts within an efficient information system.

\section{Methodology Review}

Indeed, most research has aimed at facing the question as to which analyses are being used to assess SID (Sandahl \& Sjörgren, 2003). One method commonly used for SID is the Discounted Cash Flow (DCF)Analysis (Pike, 1996) (1). The DCF, also known as present value (PV) uses risk-adjusted discount rates (r) to monetise the time frame of SID (Allemann, 2002; Adler, 2000; Slagmulder et al., 1995). The cash flows ( $\left.c_{t}\right)$ are separated by their period of time (t) (for a detailed overview refer to Brealey et al., 2011). To evaluate an investment, the initial negative cash flow $\left(\mathrm{C}_{0}\right)$ is added and leads to the Net Present Value (NPV) (2).

$$
\begin{aligned}
& P V=D C F=\sum_{t=1}^{T} \frac{C_{t}}{(1+r)^{t}} \\
& N P V=C_{0}+P V=C_{0}+\sum_{t=1}^{T} \frac{C_{0}}{(1+r)^{t}}
\end{aligned}
$$

Accurate forecast of long-term measures cannot be made by comprehensively monetising (Ansoff, 1988). For instance, risk rises by involving new technology (Demchek, 1992), dynamic feedback loops in the SID (Paitch \& Sterman, 1993) and a long forecast horizon (Webb, 1994). Above all, DCF has been examined by using excessively high discount rates compared to the market standard to assess SID (Adler, 2000). Due to missing flexibility in monetising option values, DCF is most appropriate in assessing non-strategic investment, where intangible elements and risks are low (Pike, 1996). Finally, DCF is supposed to overemphasise on the short term, exclude the non-financial benefits and neglect the assessment of cross-functional and cross-departmental benefits (Adler, 2000). 
According to SID, neglecting long term effects may lead to wrong decisions (Nitzsch, 2006). The issue is the lack in considering qualitative aspects.

An established method developed for decision support in the field of economics, finance and psychology considering also qualitative aspects is the utility analysis (UA) (Cascio, 2000). In terms of system technology, UA is characterised by "organizing a multidimensional target system with a set of complex alternatives in order to set preferences according to the decision maker" (Zangemeister, 1976 - translation from German). This approach ensures that decision making process is performed systematically and comprehensible by a person or team (Kaplan \& Rubak, 1994). The value in use of an option $\left(\mathrm{U}_{\mathfrak{i}}\right)$ for all potential circumstances $(\mathrm{s})$ is defined by a weighting $\left(\mathrm{w}_{\mathrm{z}}\right)$ of the partial utility values $\left(\mathrm{u}_{\mathrm{iz}}\right)(3)$, provided that the sum of the weights $\left(\mathrm{w}_{\mathrm{z}}\right)$ equals to 1 (4). However, the so-called value synthesis of the part worth and the overall benefit requires a consistent cardinal scale and implies independent benefits from the target system (Zangemeister, 2000). Although it is important to estimate benefits, UA uses non-monetary dimensions and may lead to standard errors due to uncertainty (Alexander \& Cronshaw, 1984; Alexander et al., 1986).

$$
\begin{aligned}
& U_{i}=\sum_{z=1}^{s} u_{i z} w_{z} \\
& \sum_{z=1}^{s} w_{z}=1
\end{aligned}
$$

Since UA has become an established method (Holling, 1998), the challenge is to combine the precise measures of TPA and the advantages of UA (Reichwald et al., 1996). In particular, the investment decisions are related to monetary assessable measures, but SID need to consider non-monetary aspects as well. Hence, the need is to use classification of direct, indirect and uncertain impact classes in a team assessment (Pittermann, 1998). With respect to UA, an integration of a target system with low complexity and mapping scenarios through the use of probabilities increases transparency of the SID (Zangemeister, 2000). By the same token, the support in different kinds of applications with little temporal and personal expense is required (Weydandt, 2000). 
However, a method assimilating the precise measures DCF and the assets of the Utility Analysis is required. In addition, a holistic perception of the SID in order to quantify non-monetary aspects is needed. With regard to the UA, the implementation of weightings in order to prioritise the sequence of investment is required. In compliance with these requirements, the method has to use the accuracy of DCF as well as the monetary evaluation dimension. Finally, the method has to be non-complex and easy to perform, leading to less expenditure of time and less effort.

\section{Profitability estimation focused on benefits (PEFB)-method}

The PEFB-method (Savelsberg, 2008) is a holistic, participation-oriented approach for the evaluation of costs and benefits of an investment (Unger, 1998). This approach combines precise measures of financial accounting with the usage of an interdisciplinary investment team to reduce bias in decision making process for non-monetary aspects. By assessing non-monetary aspects in an interdisciplinary investment team with different kinds of hierarchical levels, the transparency through SID is increased. Furthermore, the method requires less expense regarding financial and temporal effort and is also transferable to other application cases.

Based upon the utility analysis by Nagel (Nagel, 1988) and the profitability analysis of IT-investment by Ott (1992), Weydandt (2000) expands this approach for technical investment. Not only measurable monetary factors are considered, such as costs and revenues, but also a quantification of non-monetary aspects is included, such as time, quality, flexibility or the enterprise environment (Strina et al., 2003). With regard to the problem-solving process (Sell \& Schimweg, 2002), Figure 1 shows an overview of the PEFB-method (Jursch et al., 2010; Strina et al., 2003).

The PEFB-methods consists of seven steps, which are in detail:

1. constitution of the interdisciplinary investment team,

2. current situation analysis,

3. target situation analysis, 
4. compilation of measures,

5. investment evaluation,

6. planning of actions and

7. reflection.

Step 1 is concerned with building a representative interdisciplinary investment team consisting of involved executives and employees. Hence, not only the affected departments are represented, but also the various levels of hierarchy. This team will be responsible to conduct the whole evaluation, implementation and reflection process. By building up an interdisciplinary investment team and with the support of a facilitator, a holistic view on the SID is ensured. Within the current state analysis (step 2), skills and competencies inside the enterprise are identified. Furthermore, by means of the target state analysis (step 3), the strategically, tactical and operational objectives of the project are identified and noted in a specification sheet. Step 4 executes a compilation of concrete measures to achieve the target state.

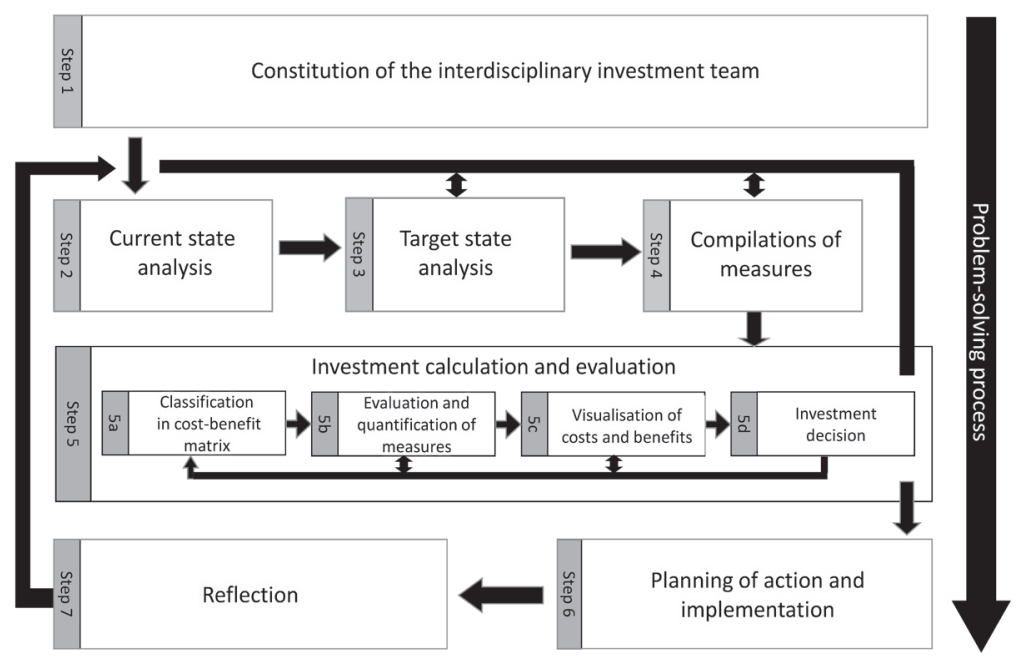

Figure 1: The PEFB-method (Source: Uribe, K. Henning, G. Strina: Measurement of Participation-oriented Evaluation: NOWS. In: Knowledge is Orange - Industry-Focused Applications of Knowledge Management across Germany. 2004) 
In step 5, the investment calculation and evaluation is carried out through four sub tasks (Strina et al., 2003). As shown in Figure 1, it encompasses the classification of costs and benefits, the evaluation and quantification of measures, visualisation of cost and benefits as well as the investment decision. The method uses two different portfolios to classify the measures. One portfolio for the benefit classification (see Figure 2) and another for the cost classification (see Figure 3). Costs and benefits of the investment are defined and assigned in terms of their impact on the project as "direct", "indirect" or "difficult to ascertain".

\begin{tabular}{|c|c|c|c|c|}
\cline { 3 - 5 } \multicolumn{2}{c|}{} & \multicolumn{3}{c|}{ Probability of occurrence } \\
\cline { 3 - 5 } \multicolumn{2}{c|}{} & High & Medium & Low \\
\hline \multirow{3}{*}{} & Direct & $\mathbf{1}$ & $\mathbf{3}$ & $\mathbf{6}$ \\
\cline { 2 - 5 } & Indirect & $\mathbf{2}$ & $\mathbf{5}$ & $\mathbf{8}$ \\
\cline { 2 - 5 } & $\begin{array}{c}\text { Difficult to } \\
\text { ascertain }\end{array}$ & $\mathbf{4}$ & 7 & $\mathbf{9}$ \\
\hline
\end{tabular}

Figure 2: Benefit portfoli

\begin{tabular}{|c|c|c|c|c|}
\hline & \multicolumn{3}{|c|}{ Probability of occurrence } \\
\hline & & High & Medium & Low \\
\hline \multirow{3}{*}{ 岁 } & Direct & 9 & 7 & 4 \\
\hline & Indirect & 8 & 5 & 2 \\
\hline & $\begin{array}{l}\text { Difficult to } \\
\text { ascertain }\end{array}$ & 6 & 3 & $\mathbf{1}$ \\
\hline
\end{tabular}

Figure 3: Cost portfolio

Direct costs or benefits are those which are related to the investment so that the impact can be measured directly, e.g. acquisition costs or increase of productivity. Accordingly, indirect costs or benefits are a derivate from direct effects, for instance maintenance cost or increased quality. Finally, "difficult to ascertain" costs or benefits contain effects which can only be presumed, like demotivation of employees or improving the image of the company. Moreover, the measures are classified regarding their probabilities of occurrence into the classes high, medium and low. Each cell of the matrix contains a so called risk level, reaching from 1 to 9. Meanwhile direct benefits with high probability are assigned with the 
risk level 1 (refer to Figure 2), the risk levels in the cost portfolio (see Figure 3) are arranged contrarily. Hence, direct costs with high probabilities are assigned to the risk level 9.

In the framework of the visualisation, the risk levels define a ranking scale of measures (Nagel, 1988). After the classification and quantification of the aspects, the filled cells of the matrix are aligned in two numerical series. The overall benefits $\left(B_{n}\right)$ for a risk level $(j)$ are computed from the summation of the single benefits $\left(b_{j}\right)(5)$. The calculation of the overall costs $\left(C_{m}\right)$ for a risk level $(j)$ of the individual costs $\left(c_{j}\right)$ is done accordingly (6).

$$
\begin{gathered}
B_{n}=\sum_{j=1}^{9} b_{j} \\
C_{m}=\sum_{j=1}^{(9-m)+1} c_{j}
\end{gathered}
$$

The cumulated values are added according to their risk level scale (Jursch et al., 2010; Strina et al. 2003). The value of each risk level is recorded in a risk oriented chart (see Figure 4). In relation to the possible intersection situations, four general cases can be distinguished. On the one hand, when the cost function is beneath the benefit function in all nine levels, the investment is economically evaluated as recommendable without restrictions. On the other hand, if the cost function is always above the benefit function, the investment is evaluated as definitely uneconomical. Finally, in the case of an intersection of both curves, an interpretation of the risk-level is required.

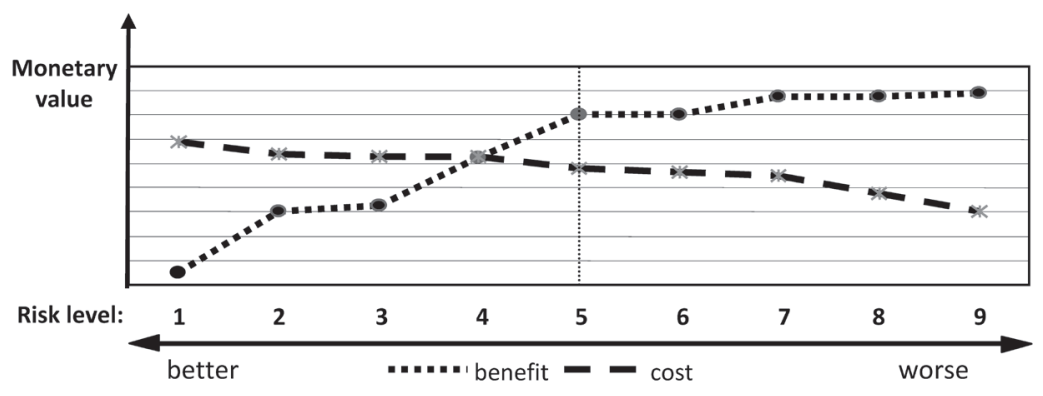

Figure 4: Risk levels visualisation based on costs-benefits evaluation 
Investment scenarios with an intersection of both graphs in the risk level 1 are the most economically reasonable (better). In terms of the descriptive interpretation, the overall costs are exceeded by direct and highly probable benefits. According to the alignment, if the intersection point is located to a greater extent to the left of risk level 5, the investment is more recommendable. Contrarily, the worst economically reasonable investment scenario is a location of the intersection point at the risk level 9 (worse). Hence, direct and highly probable costs go beyond all possible benefits. Thus, the investment is getting worse exceeding benefit risk level 5 .

In step 6 (planning of action or implementation - depending on the results of the assessment), the next actions towards the investment decision are determined. In particular, the advice for the evaluation of strategies is directly incorporated into the transfer process. Finally, the interdisciplinary investment team appraises the experiences gathered during the process step 7. Accordingly, in the reflection phase a review of the whole investment evaluation process is carried out and appropriate recommendations are made.

\section{The experimental design}

In general, there is a substantial need to assess also long-term effects for the evaluation of SID, thus an estimation of the probabilities of occurrence is used. This estimation is realised in PEFB-method by an interdisciplinary investment team. The team consists of different hierarchical levels with various attitudes towards the SID. Due to the various attitudes, an effect on quality of the results is supposed. Thus, in order to investigate the effect of verbal probabilities in the context of personal affection, a survey was conducted. According to the used probability terms of low, medium and high in the PEFB-method, the definition of the boundaries regarding the used probability terms has to be analysed.

H1: The perception of risks in investments is influenced by personal affection in group decisions which leads to a bias in probability evaluation with regard to the low and medium boundary. 
H2: The perception of risks in investments is influenced by personal affection in group decisions which leads to a bias in probability evaluation with regard to the medium and high boundary.

The Participants were recruited randomly and the duration of the survey was about 10 minutes. Furthermore, the participants' social demographical background, like age and profession were assessed. Within the 24 items of the survey, 14 items were related to investigate the bias in probability assessment due to personal affection. The risk attitude was assessed by a point scale (1=risk-averse, 5=risk seeking). Furthermore, personal affection was assessed by four items on an open scale. The following questions are examples of items to determine the personal affection.

Q1 (investment_small): Imagine you buy an electric pineapple peeler for kitchen use. With the help of this device, you expect to peal fast and easy. Moneywise, you take no financial risks. For you, what would be a low, medium respectively high probability to satisfy your demands or to be dissatisfied with your investment?

Q2 (investment_big): Imagine you buy a large tenement with the goal of economic success in the long-run. The rents received ought to contribute essentially to your financial security in your retirement. Financially, you take a risk by buying. For you, what would be a low, medium respectively high probability to regard the investments not profitable (e.g. by building an incineration plant in striking distance to rental property, high vacancy, high repair costs etc.)?

\section{Results}

Table 1 shows detailed information regarding the number of participants (N), mean value (M) and standard Deviation (SD) of the survey. The majority of the participants are employees (40.9\%) or students with a master degree (31.8\%) followed by executives (14.5\%). The average age of the participants was 32.55 years $(\mathrm{SD}=11.62)$.

Most of the participants stated that they are risk-averse in general, although their attitude towards risks of everyday life is associated with risk 
seeking. An exception is formed by the attitude towards risks of natural forces by high risk aversion. Average measures in sample for investment without personal affection show boundary values for low to medium of $32.26 \%$ and $68.75 \%$ for medium high probabilities. This results decrease for personal affection to the boundary value of low to medium to $26.49 \%$ and for the boundary value of medium to high to $57.51 \%$.

Table 1: Descriptive data of the study variables

\begin{tabular}{|l|c|c|c|}
\hline variable & $\boldsymbol{N}$ & $\boldsymbol{M}$ & $\boldsymbol{S D}$ \\
\hline Attitude towards risks & 110 & 2.23 & 1.17 \\
\hline Attitude towards risks of everyday life & 110 & 3.48 & 1.12 \\
\hline Attitude towards risks of natural forces & 110 & 2.07 & 1.12 \\
\hline $\begin{array}{l}\text { Investment boundary low to medium } \\
\text { (low personal affection) }\end{array}$ & 110 & 32.26 & 13.85 \\
\hline $\begin{array}{l}\text { Investment boundary medium to high } \\
\text { (low personal affection) }\end{array}$ & 110 & 68.75 & 16.02 \\
\hline $\begin{array}{l}\text { Investment boundary low to medium } \\
\text { (high personal affection) }\end{array}$ & 110 & 26.49 & 15.48 \\
\hline $\begin{array}{l}\text { Investment boundary medium to high } \\
\text { (high personal affection) }\end{array}$ & 110 & 57.51 & 19.96 \\
\hline
\end{tabular}

To test the hypothesis, an independent-sample t-test was conducted. Table 2 shows the results of the analysis with regard to the boundaries of mean value due to personal affection (PA) and the t-test ( $t$ ).

Table 2: Results of independent-sample t-test for investment risk at low to medium and medium to high level in dependence on personal affection

\begin{tabular}{|l|c|c|c|c|}
\hline variable & N & M (PA =low) & M (PA = high) & t \\
\hline Investment risk low to medium level & 110 & 32.257 & 26.494 & $2.911^{* * *}$ \\
\hline Investment risk medium to high level & 110 & 68.751 & 57.5055 & $4.609^{* * *}$ \\
\hline
\end{tabular}

Significant differences in perception of investments risk at low to me$\operatorname{dium}(t=32.257, p<.001)$ as well as medium to high level $(t=26.494, p$ $<.001$ ) were found. As proposed in hypothesis 1, people that are personally affected differ in their estimation of investment risks from low to medium boundary in comparison to participants that are not personally affected. In fact, people also differ in the estimation of investment risks 
from medium to high boundary in comparison to not personally affected participants. To that effect, applying PEFB-method entails some risks regarding the validity of the results. These risks have to be considered and eliminated by conceptual adaption.

\section{Conclusion}

Current research addressing the assessment of SID consistently demonstrates that there is a need for more comprehensible methods. The focus of these methods should rely on theoretically and adaptive approaches. Identifying and evaluating the long-term effects under uncertainty and risk is the main research challenge. Without knowledge about the effects, forecasting and evaluation of SID will be hazardous. One way to meet this challenge is applying the PEFB-method.

The contribution of this paper is the examination of the PEFB-method regarding the conceptual design and the challenges in applying for SID. In particular, the findings of the survey give evidence to a bias due to personal affection regarding the classification of occurrence probabilities. Within the scope of the PEFB-method, wrong alignment of probabilities under the assumption of fixed cost benefit components lead to an average bias of 2.6 risk levels. That implies a movement of the cost or benefit graph by the same amount of risk levels. This results in movement of the intersection point and the results of the method as well.

The findings of this study induce some critical reflections. These critical reflections are related to a superordinate and a method-orientated frame of reference. Within the scope of critical reflections to superordinate aspects, the interdisciplinary investment team are just interacting components. Owing to the psychological phenomena of "Groupthink" (Mullen et al., 1994) the conformity of the group is weighted higher than the result of the assessment. Besides these facts, there are also interrelations among the interdisciplinary team, like the impact of hierarchies, know-how and practical knowledge. In particular, personal commitment related to the 
company and the SID as well as professional experience may promote bias in probability estimation by group decision.

Furthermore, within the method-oriented frame of reference unambiguous definitions of the SID result in inconsistent considerations. Hence a fine grasp of every step of the PEFB-method just like a clear instruction of the computational rule of the investment decision has to be given. From that point of view, group discussion has to be managed sensitively.

Further research should focus on setting up a new survey in order to investigate the effects of facilitating the PEFB-method, the influence of hierarchies and the impact of different know-how among the interdisciplinary investment team. To ensure the validity of the results of the PEFB-method, an examination of the reliability is necessary. Currently, validation workshops provide evidence that the proved bias due to personal affection is a systematic error. Therefore, future research should focus on methods to eliminate this systematic bias through personal affection. Possible methods might be algorithms to support group process assessment and to ensure a common understanding of probability terms. In particular, artificial intelligence (AI)-based methods like Markov chain, Bayesian networks or a fuzzy-logic might be promising.

\section{References}

ACCOLA, W.L. (1994): Assessing risk and uncertainty in new technology investments. Accounting Horizons 8, pp. 19-35.

ADLER, R.W. (2000): Strategic investment decision appraisal techniques: the old and the new. Business Horizons 43 (6), pp. 15-22.

ALESSANDRI, T.; Ford, D.N.; Lander, D.M.; Leggio, K.B.; Taylor, M. (2004): Managing risk and uncertainty in complex capital projects. Quarterly Review of Economics and Finance 44, pp. 751-767.

ALEXANDER, R.A.; Cronshaw S.F. (1984): The utility of selection programs: A finance-based perspective. 92nd annual Convention of the American Psychological Associations. Toronto, Canada.

ALEXANDER, R.A.; Cronshaw S.F.; Barrick, M.R. (1986): Extending the managerial finance model of utility analysis to deal with uncertainty in parameter estimates. 1st annual conference of the Society for Industrial and Organizational Psychology, Chicago. 
ALKARAAN, F.; Northcott, D. (2006): Strategic capital investment decision-making: a role for emergent analysis tool? A study of practise in large UK manufacturing companies. British Accounting review 38 (2), pp. 603-626.

ALlEMANN, J. (2002): A new view of telecommunications technologies. Telecommunications Policies 26, pp. 87-92.

ANSOFF, H. I.: (1988): The new Corporate Strategy. John Wiley and Sons, New York, p.30.

BREALEY, R.A.; Myers, S.C.; Allen, F. (2007): Fundamentals of Corporate Finance. 5th Edition. New York: Mc Graw-Hill/Irwin, Chapter 8, pp. 222-248.

CARR, C.; Kolehmainen, K.; Mitchell, F. (2010): Strategic investment decision making practise: A contextual approach. Management Accounting Research 21, pp. 167-184.

CASCIO, W.F. (2000): Costing Human Resources: The financial impact of Behaviour in organizations, fourth edition. Southwestern College Publishing, Cincinnati.

CORNELIUS, P.; Van de Putte, A.; Romani M. (2005): Three decades of scenario planning in shell. California Management Review 48, pp. 92-111.

DEMCHEK, C.C. (1992): Complexity, rogue outcomes and weapons systems. Public Administration Review 52 (4), pp. 347-355.

DEMPSEY, M.J. (2003): A multidisciplinary perspective on the evaluation of corporate investment decision making. Accounting, Accountability \& Performance 9 (1), pp. 1-33.

GRAHAM, J.R.; Harvey, C.R. (2001): The theory and practice of corporate finance: evidence from the field. Journal of Financial Economics 60, pp. 187-243.

HOLLING, H. (1998): Utility Analysis Of Personnel Selection. An Overview And Empirical Study Based On Objective Performance Measures. Methods of Psychological Research Online 3 (1).

JURSCH, S.; Bischoff, S.; Hauck, E.; Flachskampf, K.H.; Jeschke, S. (2010): Value Oriented Cost-effectiveness Estimation of Innovative Intermodal Loading Unit. International Journal of Trade, Economics and Finance 1 (3), pp. 271-276.

KAPLAN, S.N.; Ruback, R.S. (1994): The Valuation of Cash Flow forecast: An empirical analysis. Working Paper No. 4724. National Bureau of economic research. Massachusetts, Cambridge, MA 02138.

MARTZOUKOS, S.H.; Trigeorgis, L. (2002): Real (investment) options with multiple source of rare events. European Journal of Operational Research 136, pp. 196-206.

MILLER, K.D.; Waller, H.G. (2003): Scenarios, real options and integrated risk management. Long Range Planning 36, pp.93-107.

MULLEN, B.; Anthony, T.; Salas, E.; Driskell, J.E. (1994): Group Cohesiveness and quality of decision making. An integration of tests of the Groupthink Hypothesis. Small Group Research, 25 (2), pp. 189-204.

NAGEL, K. (1988): Nutzen der Informationsverarbeitung: Methoden zur Bewertung von strategischen Wettbewerbsvorteilen, Produktivitätsverbesserung und Kosteneinsparung. Oldenburg.

NITZSCH, R.v. (2006): Entscheidungslehre. 1. Auflage, Aachen, Mainz GmbH.

OTT, H.J. (1993): Wirtschaftlichkeitsanalyse von EDV-Investitionen mit dem WARS-Modell am Beispiel einer Einführung von CASE. Wirtschaftsinformatik, 35 (6), pp. 522-531.

PAITCH, M.; Sterman, J.D. (1993): Boom, bust, and failures to learn in experimental markets. Management Science 39 (12), pp. 1439-1458.

PIKE, R. (1996): A longitudinal survey of capital budgeting practises. Journal of Business Finance and Accounting 23 (1), pp. 79-92. 
PITTERMANN, P. (1998): Erfolgspotentialerfassung: Betriebswirtschaftliche Bewertung ganzheitlicher Veränderungsprozesse dargestellt an Fallbeispielen aus dem Qualitätsmanagement. Eschborn.

PREIßLER, P. (1991): Führen mit Kennzahlensystemen: Unverzichtbares Instrumentarium, in: Gablers Magazin 3/1991, Wiesbaden.

REICHWALD, R.; Höfer, C., Weichselbaumer, J. (1996): Bewertung von Reorganisationsprozessen. Stuttgart.

SANDAHL, G.; Sjögren, S. (2003): Capital budgeting methods among Sweden's largest groups of companies. The state of the art and a comparison with earlier studies. International Journal of Production Economics 84 (1), pp. 51-69.

SLAGMULDER, R.; Bruggeman, W.; Van Wassenhove, L. (1995): An empirical study of capital budgeting practices for strategic investments in CIM technologies. International Journal of Production Economics 40 (2-3), pp. 121-152.

SLAGMULDER, R. (1997): Using management control systems to achieve alignment between strategic investment decisions and strategy. Management Accounting Research 8 (1), pp. 103-139.

STRINA, G.; Uribe, J.; Henning, K. (2003): NOWS Technique: Participation oriented Evaluation of further Education Strategies and Measures. Proceedings of E-Learning 2003. World Conference on E-learning in Corporate, Government, Healthcare \& Higher Education, pp. 331-337.

SAVELSBERG, E. (2008): Innovation in European freight transportation - basic, methodology and case studies for the European markets. Berlin, Springer-Verlag.

SCHÖNHEIT, M. (1996): Wirtschaftliche Prozeßgestaltung - Entwicklung, Fertigung, Auftragsabwicklung. Berlin.

SELL, R.; Schimweg, R. (2002): Probleme lösen: In Komplexen Zusammenhängen Denken. 6. überarbeitete Auflage. Berlin, Springer-Verlag.

UNGER, H. (1998): Organisationales Lernen durch Teams. Rainer Hampp Verlag, München.

VAN CAUWENBERGH, A.V.; Durinck, E.; Martens, R.; Laveren, E.; Bogaert, I. (1996): On the role and function of formal analysis in strategic investment decision processes: results form an empirical study in Belgium. Management Accounting Research 7 (2), pp. 169-184.

WEBB, G.K. (1994): Electronic industry model: a report on two decades of implementation. International Journal of Forecasting 10 (4), pp. 583-596.

WEYDANDT, D. (2000): Beteiligungsorientierte wirtschaftliche Bewertung von technischen Investitionen für prozeßorientierte Fertigungsinseln. Aachen, Shaker Verlag.

ZANGEMEISTER, C. (1976): Nutzwertanalyse in der Systemtechnik - Eine Methodik zur multidimensionalen Bewertung und Auswahl von Projektalternativen. Diss. Techn. Univ. Berlin 1970, 4. Aufl., München: Wittemann.

ZANGEMEISTER, C. (1994): Erweiterte Wirtschaftlichkeitsanalyse (EWA), in: Fortschrittliche Betriebsführung und Industrial Engineering 43, S. 63-71.

ZANGEMEISTER, C. (2000): Erweiterte Wirtschaftlichkeitsanalyse: (EWA) ; Grundlagen, Leitfaden und PC-gestützte Arbeitshilfen für ein "3-Stufen-Verfahren" zur Arbeitssystembewertung. 2. überarbeitete Auflage. Bremerhaven: Wirtschaftsverlag NW, Verlag. für Neue Wissenschaft. 
Série Investigação

Imprensa da Universidade de Coimbra

Coimbra University Press

2015

mais

Programa Operacional Regional do Centro

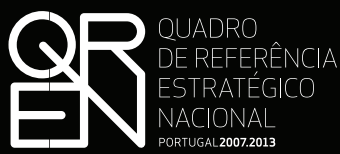

PORTUGAL 2007.2013

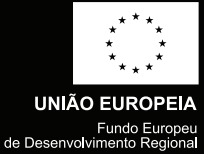

- $\mathbf{U}$

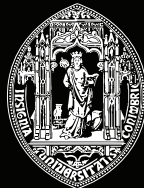

C •

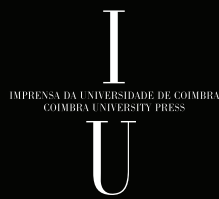

